\title{
Impact of Global Financial Crisis on Stock Market Volatility: Evidence from India
}

\author{
P. Sakthivel ${ }^{1}$, K. VeeraKumar ${ }^{1}$, G. Raghuram ${ }^{2}$, K. Govindarajan ${ }^{2} \&$ V. Vijay Anand ${ }^{2}$ \\ ${ }^{1}$ Department of Commerce and Management Studies, Srinivasa Ramanujan Centre, SASTRA University, \\ Kumbakonam, Tamilnadu, India \\ ${ }^{2}$ School of Management, SASTRA University, Tirumalaisamudram, Thanjavur, Tamilnadu, India \\ Correspondence: P. Sakthivel, Department of Commerce and Management Studies, Srinivasa Ramanujan Centre, \\ SASTRA University, Kumbakonam, Tamilnadu, India. E-mail: sakthivel@mba.sastra.edu
}

Received: January 10, 2014 Accepted: April 24, $2014 \quad$ Online Published: April 29, 2014

doi:10.5539/ass.v10n10p86 URL: http://dx.doi.org/10.5539/ass.v10n10p86

\begin{abstract}
This paper studies the global financial crisis and the effect of the crisis on stock market volatility by employing the GJR GARCH model. Daily closing price of indices in the National Stock Exchange (NSE) and the Mumbai Stock Exchange (BSE) from March $1^{\text {st }}, 2005$ to December $30^{\text {th }} 2012$ were considered for the analysis. The study covers two periods: pre-crisis (from March 01, 2005 to January, 30 2008) and post-crisis (from February 01, 2008 to December 30,2012). To demonstrate the influence of crisis on stock returns volatility, a dummy variable was introduced in the GJR GARCH model. It is found that the volatility of mean returns had increased during the post crisis period as compared to the pre-crisis period. The findings also suggest that the recent financial crisis had an adverse impact on mean returns and the volatility in the Indian stock market.
\end{abstract}

Keywords: global financial crisis, volatility, and GJR GARCH model

\section{Introduction}

The sub-prime lending crisis in US economy spread across the entire world causing a global financial crisis. The financial crisis that originated in USA and shook the world had little impact on Indian stock market, because of the strong economic fundamentals in India and less exposure of Indian stock market to the international equity markets. As a result of U.S. sub-prime lending crisis, foreign institutional investors had to pull out their investments from the Indian stock market. The net outflows of FII were \$15,017 million in 2008-2009 and these outflows affected the Indian stock market considerably.

The regulatory authorities in India were very much concerned about the impact of the global financial crisis on the Indian stock market. A highly volatile market with negative returns would naturally affect the Indian capital market and the Indian economy. Many studies show that volatility stock markets across the world had increased after global financial crisis (Verma \& Mahajan, 2012; Ali \& Afzal, 2012; Adamu, 2010). Verma and Nayia Mahajan (2012) found that volatility had been highest during the crisis period and it came down during the post crisis period. Similarly Ali and Muhammad (2012) found recent financial crisis contributed to volatility in stock returns. However, Karunanayake and Brien (2010) state that recent global financial had no any significant impact on stock returns. Therefore it is important to study the impact of global financial crisis on spot market volatility in India.

\section{Some Empirical Evidences}

Petr Sed' (2012) examined the impact of the global financial crisis on Central European stock market volatility by studying the Czech and Polish stock markets. Further the study analyzed the stock volatility in the markets before, during and after the crisis. The study used the Jump-Diffusion GARCH model considering heteroskedasticity which has greater accuracy than simple GARCH type volatility models. The results of this study showed that volatility of the stock markets in these countries had increased during global financial crisis. Rafaqet Ali and Muhammad Afzal (2012) analyzed the effect of global financial crisis on the volatility in Pakistan and Indian stock market by employing EGARCH. They considered the daily closing price of KSE-100 and BSE-100 indices from $3^{\text {rd }}$, January 2003 to $31^{\text {st }}$, August 2010 for their analysis. The empirical results revealed that the global financial crisis had adversely affected stock returns and increased the volatility in Indian 
and Pakistani stock markets.

Choy Yoke Chong (2011) analyzed the effect of sub-prime lending crisis on volatility of US stock returns. The daily closing price of S\&P 100 from May 2006 to December 2009 was considered for the analysis. The study employed the GARCH model to capture volatility clustering phenomena in data. His results showed that the sub-crime lending crisis increased the volatility in the US stock market but did not have any significant impact on stock returns. Samer Al-Rjoub and Hussam Azzam (2012) investigated the impact of the US Sub-prime lending crisis on the behaviour stock returns in the emerging markets. They used daily closing price of stock prices from 1992 to 2009. Their results showed that stock prices had fallen drastically and that they followed non normal distribution during crisis period. The finally result suggests that the crisis had adversely affected stock returns of all sectors with the banking sector being the most affected.

Sang Hoon Kang, Yea Won Eun, Seong-Min Yoon (2012) analyzed the US sub-prime lending crisis and the volatility spill over among Asian stock markets by employing the bivariate GARCH model. Their results found that there was a strong volatility transmission between the Chinese market and some of emerging markets in Asia particularly after the global financial crisis. Indika Karunanayake, Abbas Valadkhani and Martin O'Brien (2010) examined the dynamic interrelationship between stock returns and their volatility during Asian and global financial crisis. They used the weekly data of indices from Australia, Singapore, the UK and the US from 1997-1998 and 2008-2009. Using MGARCH model, they found evidence that there was no significant effect on mean returns due to the two crises. The two crises however increased the stock market volatility.

Amir Angabini and Shaista Wasiuzzaman (2010) investigated the US sub-prime crisis and its impact on volatility in the Malaysian stock market by employing the GARCH model. The results of this study provide evidence that the US sub-prime crisis had adversely affected stock returns and increased market volatility.

Soumya Saha and Gagari Chakrabarti (2011) examine global financial crisis and the volatility contagion among the financial markets by using GARCH model. The study covers the period from January 2006 to December 2010. The author considers three sub-periods namely pre-crisis, crisis and post crisis periods. The results indicate presence of volatility spill over but no asymmetric impact between stock to exchange rates and vice-versa during the three sub-periods.

Most of the existing studies have focused on the developed markets. There are no many papers examining the effect of global financial crisis on volatility in the Indian stock market. Hence this study makes an effort to analyze the effect of the global financial crisis on volatility in the Indian stock markets.

\section{Scope of the Study}

The impact of global financial crisis on spot market volatility is an interesting subject for regulators and policy makers all over the world. The market volatility may cause borrowing cost to shoot up and also investors may lose confidence in the market. As a result investment activity might be affected. Further, investors may shift to less volatile markets. So it is essential to study the effect of global financial crisis on stock market volatility in India.

\section{Objectives}

In light of the scope of the study mentioned above the following objectives were framed.

1) To examine trends of Foreign Institutional Investments in the Indian stock market before and after global financial crisis.

2) To examine the effect of the global financial crisis on volatility in the Indian stock market.

\section{Data and Methodology}

\subsection{Data Description}

Daily closing prices of indices Nifty 50, Nifty Junior and Nifty Midcap were taken from the official website of the National Stock Exchange (NSE), www.nseindia.com for the period January 01, 2005 to December 31, 2012. Daily closing prices of indices BSE 30 and BSE 100 were taken from the official website of the Mumbai Stock Exchange (NSE), www.nseindia.com for the same period. The study covers the pre-crisis period (March 01, 2005 till January 30, 2008) and the post-crisis period (February 01, 2008 till December 30, 2012).

The volatility of spot market has increased during the post crisis period because foreign institutional investors pulled out their investment from Indian stock market. As per SEBI records, the foreign institutional investors' (FIIs) net inflows were Rs. 45,810 crores in 2009 (see Figure 1). 


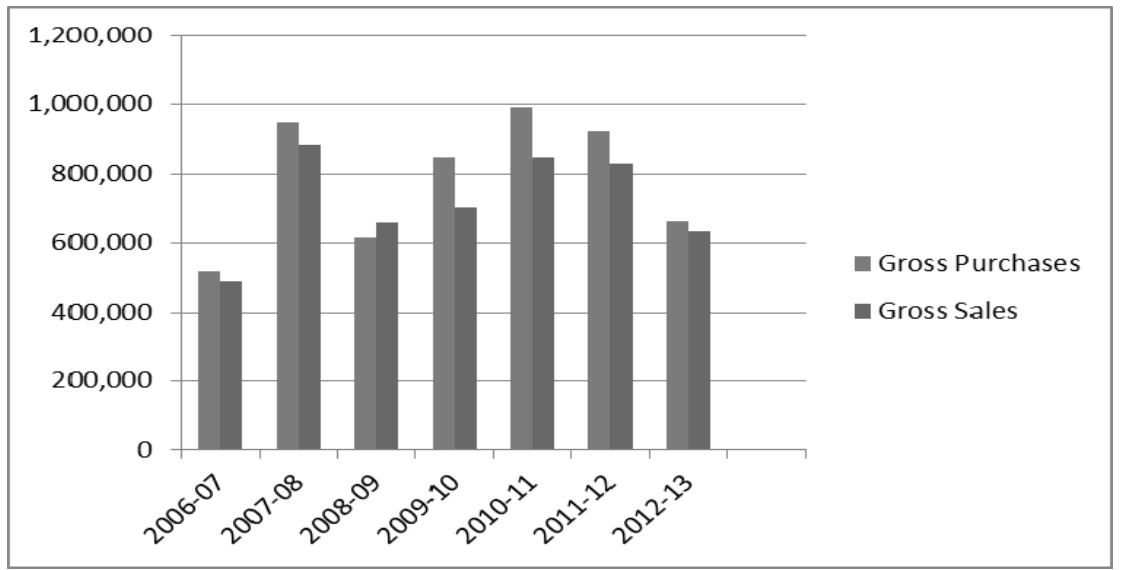

Figure 1. Gross purchases and sales of shares by FII (Units in Crore)

\subsection{Methodology}

To check whether a time series was stationary or non-stationary, Dickey and Fuller (1979) and PP Tests were used. The ADF test is based on the estimate of the following regression:

$$
\Delta \mathrm{y}_{\mathrm{t}}=\alpha_{0}+\gamma_{1} \mathrm{y}_{\mathrm{t}-1}+\sum_{\mathrm{i}=1}^{\mathrm{p}} \beta_{\mathrm{i}} \Delta \mathrm{y}_{\mathrm{t}-\mathrm{i}}+\varepsilon_{\mathrm{t}}
$$

Where, $\Delta$ is the first-difference operator, $p$ is lag, $\alpha_{0}$ is constant, $\alpha_{1}$ and $Y_{i j}$ are parameters and $\varepsilon_{\mathrm{t}}$ denotes stochastic error term. If $\gamma=0$, then the series is said to have a unit root and is non-stationary.

GJR GARCH model was used for examining the effect of global financial crisis on stock market volatility. An important limitation of GARCH models is that they impose a symmetric volatility response to positive and negative shocks. This is because the conditional variance in the below equation (2) is the magnitude of the lagged residuals and hence does not account for their signs (positive or negative). However, it is to be noted that negative shocks are likely to cause more volatility rises than positive shocks. In the context of equities such asymmetries refer to the leverage effect due to which reduction in the market capitalization of the firm's stock results in a rise in the firm's debt-equity ratio. Consequently, the equity shareholders' perception of risk increases.

The asymmetric response of conditional volatility to information can be captured by including, along with the standard GARCH variables, squared values of $\varepsilon_{\mathrm{t}-1}$ when $\varepsilon_{\mathrm{t}-1}$ is negative (Gltosan, Jagannathan, \& Runkle, 1993). The following GJR GARCH specification was estimated.

$$
\mathrm{h}_{\mathrm{t}}=\alpha_{0}+\sum_{\mathrm{j}=\mathrm{i}}^{\mathrm{q}} \alpha_{1} \varepsilon_{\mathrm{t}-1}^{2}+\sum_{\mathrm{i}=1}^{\mathrm{p}} \beta_{1} \mathrm{~h}_{\mathrm{t}-1}+\sum_{\mathrm{k}=1}^{\mathrm{r}} \gamma_{\mathrm{i}} \mathrm{I}_{\mathrm{t}-1} \varepsilon_{\mathrm{t}-1}^{2}
$$

where, $I_{\mathrm{t}-1}=1$ if $\varepsilon_{\mathrm{t}-1}<0$; $=0$ other wise.

For a leverage effect $\gamma>0$. The condition for non-negativity would now be $\alpha_{0} \geq 0, \alpha_{1} \geq 0, \beta_{1} \geq 0$ and $\alpha_{1}+\gamma_{1} \geq 0$. In the model, good news $\left(\varepsilon_{\mathrm{t}-1}>0\right)$ and bad news $\left(\varepsilon_{\mathrm{t}-1}<0\right)$, have contrasting impacts on the conditional variance, good news has an effect of $\beta_{1}$, while bad news has an effect of $\alpha_{1}+\gamma_{1}$. If $\gamma_{1}>0$, negative shocks tend to have more volatility, and is known as the leverage effect of the $i^{\text {th }}$ order. If $\gamma_{1} \neq 0$, the news effect is symmetric.

A dummy variable was introduced in the conditional mean and variance equation so as to investigate the impact of the global financial crisis on the volatility of NSE and BSE. The model modified as per the GJR GARCH approach was specified as,

$$
\begin{gathered}
\mathrm{Rt}=\alpha 0_{+} \beta_{1} \mathrm{R}_{\mathrm{t}-1+1} \gamma_{1} \mathrm{D}_{1}+\varepsilon_{\mathrm{t}} \\
\mathrm{h}_{\mathrm{t}}=\alpha_{0}+\sum_{\mathrm{j}=\mathrm{i}}^{\mathrm{q}} \alpha_{1} \varepsilon_{\mathrm{t}-1}^{2}+\sum_{\mathrm{i}=1}^{\mathrm{p}} \beta_{1} \mathrm{~h}_{\mathrm{t}-1}+\sum_{\mathrm{k}=1}^{\mathrm{r}} \gamma_{\mathrm{i}} \mathrm{I}_{\mathrm{t}-\mathrm{E}} \varepsilon_{\mathrm{t}-1}^{2}+\lambda_{1} \mathrm{D}_{1}
\end{gathered}
$$

The dummy variable D1 assumes the value zero for the pre-global financial crisis era and one for the post global financial crisis era. A negative and statistically significant coefficient for the dummy variable implies that the 
global financial crisis caused a reduction in the volatility of the Indian stock market. A positive and statistically significant coefficient for the dummy variable implies that the global financial crisis caused an increase in the volatility of the Indian stock market.

\section{Results and Discussion}

To test stationary for five indices of BSE and NSE, ADF and PP tests are employed. The results of ADF are presented in Table1. Since most of the log indices were found to be non-stationary in level form, null hypothesis was accepted. However, $\log$ indices were stationary in the first difference. Similar results were observed in the Phillips and Perron test and these are given in same table.

Table 1. Results of unit root statistics

\begin{tabular}{lllll}
\hline Name of the Index/stock & ADF in level & ADF in First Differences & PP in level & PP in First Differences \\
\hline \multirow{2}{*}{ Nifty 50} & -0.5620 & $-36.2161^{*}$ & -0.7342 & $-36.674^{*}$ \\
& $(0.456)$ & $(0.0000)$ & $(0.356)$ & $(0.0000)$ \\
Nifty Junior & -0.2456 & $-31.563^{*}$ & -0.3520 & $-31.6632^{*}$ \\
& $(0.3780)$ & $(0.0000)$ & $(0.6430)$ & $(0.0000)$ \\
Nifty Mid cap & -0.8761 & $-43.987^{*}$ & -0.2104 & $-43.988^{*}$ \\
& $(0.452)$ & $(0.0000)$ & $(0.4578)$ & $(0.0000)$ \\
BSE 30 Sensex & $-2.4530^{*}$ & $-17.3208^{*}$ & $-2.6540^{*}$ & $-18.3450^{*}$ \\
& $(0.1543)$ & $(0.0000)$ & $(0.4530)$ & $(0.0000)$ \\
BSE 100 & -0.1180 & $-38.561^{*}$ & -0.5460 & $-38.560^{*}$ \\
& $(0.4390)$ & $(0.0000)$ & $(0.5430)$ & $(0.0001)$ \\
\hline
\end{tabular}

Note: *\&* Indicates $1 \%$ and $5 \%$ significance level.

The Table 2 presents basic properties of mean standard deviation, and Jarque Berra .The measures of skewness and kurtosis revealed that the Nifty returns series were skewed and followed a non-normal distribution. The coefficient of skewness was negative for Nifty and Nifty Junior both during both the pre and post financial crisis periods. However, coefficient of skewness was found to be positive for BSE Sensex during both the pre and post financial crisis periods.

Table 2. Summary of descriptive statistics

\begin{tabular}{lllllll}
\hline & Return* & Mean & S.D & Skewness & Kurtosis & LBQ TEST \\
\hline \multirow{2}{*}{ Nifty 50 } & Pre crisis & 0.0345 & -0.5632 & -0.5790 & 8.4532 & $33.50(0.000)$ \\
& Post Crisis & -0.5470 & 0.4560 & -0.4590 & 12.450 & $48.535(0.000)$ \\
Nifty Junior & Pre crisis & 0.00570 & 0.0001 & -0.56790 & 22.543 & $101.002(0.000)$ \\
& Post Crisis & -0.5690 & 0.0784 & -0.3457 & 10.394 & $24.543(0.000)$ \\
Nifty Mid cap & Pre crisis & 0.890 & -0.0567 & -0.6701 & 14.7650 & $8.1467(0.000)$ \\
& Post Crisis & -0.6783 & 0.0453 & -0.9870 & 18.890 & $13.1976(0.000)$ \\
BSE 30 sensex & Pre crisis & 0.7801 & -0.4570 & 0.9910 & 26.780 & $19.9230(0.000)$ \\
& Post Crisis & -0.5690 & 0.7801 & 0.5670 & 13.2340 & $7.4621(0.000)$ \\
BSE 100 & Pre crisis & 0.1820 & -0.0530 & -3.6701 & 18.770 & $8.9131(0.000)$ \\
& Post Crisis & -0.00410 & 0.05670 & -0.5601 & 85.781 & $7.731(0.000)$ \\
\hline
\end{tabular}

The daily mean returns for most of indices were positive in the pre-financial crisis period. However, the daily mean returns for most indices were negative in the post financial crisis period. (Refer Appendix A). This indicates that the global financial crisis had an adverse impact on stock returns. The descriptive statistics showed that the standard deviation of most indices had increased in the post crisis period as compared to pre-crisis period. This implies that the volatility of indices from BSE and NSE had increased in the post financial crisis period.

The results of GJR-GARCH models are presented in Table 3 . The coefficients for asymmetric $(\lambda 1)$, ARCH $(\alpha 1)$ 
and GARCH ( $\beta 1)$ were found to highly significant. The coefficient of ARCH was positive and significant which implies that past news impacts current volatility. So, ARCH effect is present in Nifty series. Further, a coefficient of GARCH $(0.46923)$ was positive and significant which implied that volatility clustering was present in Nifty data. The asymmetric effect captured by $\lambda 1$ was positive and significant indicating that the presence of asymmetric effect in Nifty series. This implies that negative shocks news tends to increase volatility more than positive shocks.

Table 3. Results of GJR GARCH model with Nifty index

\begin{tabular}{llll}
\hline $\begin{array}{l}\text { Mean Equation } \\
\text { Parameters }\end{array}$ & Coefficients & Z-statistic & p-value \\
\hline$\beta_{0}$ & 0.0009 & 0.5680 & 0.1345 \\
$\beta_{1}$ & 4.9870 & $3.3490^{*}$ & 0.0000 \\
Variance Equation & & & \\
$\alpha_{0}$ & 0.087 & $1.890^{*}$ & 0.0021 \\
$\alpha_{1}$ & 0.5480 & $4.5489^{*}$ & 0.0000 \\
$\beta_{1}$ & 0.46923 & $8.6790^{*}$ & 0.0000 \\
${ }_{\lambda}$ Asymmetric effect) & 0.04320 & $3.6780^{*}$ & 0.0000 \\
Residual diagnostics Test statistic P. value & & & \\
L B-Q(16) & 2.560 & 0.25601 & \\
LB ${ }^{2}-\mathrm{Q}(16)$ & 4.670 & 0.35690 & \\
LM-(10) & 10.670 & 0.0100 & \\
F-Test & 0.3908 & 0.3780 & \\
\hline
\end{tabular}

Note: * Indicates $1 \%$ significance level.

The study employed the GJR GARCH model to investigate the impact of global financial crisis on spot market volatility. In order capture volatility, a dummy variable was included in the mean and variance equation; D1 takes the value zero and one for pre and post financial crisis period respectively. The results of GJR GARCH model are given Table from 4 to 8. The empirical results show that coefficient of dummy variable for Nifty in the mean equation was negative and significant. The coefficient of dummy variable for BSE Sensex in mean equation was also negative and significant. It indicates that US sub-prime lending crisis had adversely affected the stock returns of the NSE and the BSE.

Table 4. Estimates of GJR GARCH $(1,1)$ with Nifty index

\begin{tabular}{llll}
\hline $\begin{array}{l}\text { Mean Equation } \\
\text { Parameters }\end{array}$ & Coefficients & Z-statistic & p-value \\
\hline$\beta_{0}$ & 0.000450 & 0.3370 & 0.2340 \\
$\beta_{I}$ & 2.4836 & $8.7890^{*}$ & 0.0000 \\
$\gamma_{1}$ & -0.6790 & 2.4301 & 0.0001 \\
Variance Equation & & & \\
$\boldsymbol{\alpha}_{0}$ & 0.00016 & $1.890^{*}$ & 0.0021 \\
$\alpha_{I}$ & 0.5780 & $7.560^{*}$ & 0.0000 \\
$\beta_{I}$ & 0.3923 & $10.430^{*}$ & 0.0000 \\
$\lambda l$ & 0.00457 & $4.560^{*}$ & 0.0000 \\
$\delta_{2}$ (Dummy) & 0.00021 & $3.5701^{*}$ & 0.0000 \\
Residual diagnostics Test statistic P. value & & \\
L B-Q(16) & 4.670 & 0.45670 & \\
LB ${ }^{2}$-Q(16) & 3.670 & 0.67010 & \\
LM-(10) & 18.856 & 0.12000 & \\
F-Test & 0.4560 & 0.5670 & \\
\hline
\end{tabular}

Note: $* * *$ Indicates $1 \%$ significance level. 
Table 5. Estimates of GJR GARCH $(1,1)$ with Nifty junior

\begin{tabular}{llll}
\hline $\begin{array}{l}\text { Mean Equation } \\
\text { Parameters }\end{array}$ & Coefficients & Z-statistic & p-value \\
\hline$\beta_{0}$ & 0.0056 & $2.670^{*}$ & 0.0001 \\
$\beta_{I}$ & 2.5670 & $4.670^{*}$ & 0.0001 \\
$\gamma_{I}$ & -2.6780 & 3.7901 & 0.0001 \\
Variance Equation & & & \\
$\boldsymbol{\alpha}_{0}$ & 0.3789 & $4.5601^{*}$ & 0.0000 \\
$\alpha_{I}$ & 0.5673 & $8.2390^{*}$ & 0.0000 \\
$\beta_{I}$ & 0.3023 & $9.850^{*}$ & 0.0000 \\
$\lambda I$ & 0.3286 & $4.753^{*}$ & 0.0000 \\
$\delta_{2}$ (Dummy) & 0.00045 & $1.450^{*}$ & 0.0000 \\
Residual diagnostics Test statistic P. Value & & \\
L B-Q(16) & 5.890 & 0.5230 & \\
LB ${ }^{2}$-Q(16) & 3.852 & 0.6459 & \\
LM-(10) & 2.856 & 0.4236 & \\
F-Test & 0.279 & 0.556 & \\
\hline
\end{tabular}

Note: * Indicates $1 \%$ significance level.

Table 6. Estimates of GJR GARCH $(1,1)$ with Nifty mid cap

\begin{tabular}{llll}
\hline $\begin{array}{l}\text { Mean Equation } \\
\text { Parameters }\end{array}$ & Coefficients & Z-statistic & p-value \\
\hline$\beta_{0}$ & 0.00459 & $2.456^{*}$ & 0.0000 \\
$\beta_{I}$ & 3.5690 & $4.670^{*}$ & 0.0000 \\
$\gamma_{I}$ & -0.5670 & 2.5690 & 0.000 \\
Variance Equation & & & 0.0000 \\
$\boldsymbol{\alpha}_{\boldsymbol{0}}$ & 0.00240 & $2.780^{*}$ & 0.0000 \\
$\alpha_{1}$ & 0.5680 & $5.2190^{*}$ & 0.0000 \\
$\beta_{I}$ & 0.3349 & $7.5501^{*}$ & 0.0000 \\
$\lambda_{I}$ & 0.4286 & $3.753^{*}$ & 0.0000 \\
$\delta_{2}($ Dummy) & 0.00056 & $3.156^{*}$ & \\
Residual diagnostics Test statistic P. value & & \\
L B-Q(16) & 2.890 & 0.4580 & 0.780 \\
LB ${ }^{2}-\mathrm{Q}(16)$ & 7.852 & 0.2236 & \\
LM-(10) & 5.856 & 0.3560 & \\
F-Test & 0.279 & & \\
\hline Note: & & & \\
\hline
\end{tabular}

Note: * Indicates $1 \%$ significance level.

Table 7. Estimates of GJR GARCH $(1,1)$ with BSE 30 sensex

\begin{tabular}{llll}
\hline $\begin{array}{l}\text { Mean Equation } \\
\text { Parameters }\end{array}$ & Coefficients & Z-statistic & p-value \\
\hline$\beta_{0}$ & 0.00567 & $2.670^{*}$ & 0.0000 \\
$\beta_{1}$ & 1.7890 & $5.7890^{*}$ & 0.0000 \\
$\gamma_{1}$ & -0.6790 & 1.5670 & 0.000 \\
Variance Equation & & & \\
$\alpha_{0}$ & 0.0780 & 1.4861 & 0.0000 \\
$\alpha_{1}$ & 0.5853 & $7.4580^{*}$ & 0.0000 \\
\hline
\end{tabular}




\begin{tabular}{llll}
\hline $\begin{array}{l}\text { Mean Equation } \\
\text { Parameters }\end{array}$ & Coefficients & Z-statistic & p-value \\
\hline$\beta_{I}$ & 0.4023 & $5.450^{*}$ & 0.0000 \\
$\lambda_{I}$ & 0.3670 & $2.5401^{*}$ & 0.0000 \\
$\delta_{2}$ (Dummy) & 0.0056 & $3.456^{*}$ & 0.0000 \\
Residual diagnostics Test statistic P. value & & \\
L B-Q(16) & 9.890 & 0.0230 & \\
LB ${ }^{2}$-Q(16) & 4.852 & 0.3459 & \\
LM-(10) & 6.856 & 0.4236 & \\
F-Test & 0.279 & 0.5790 & \\
\hline
\end{tabular}

Note: *Indicates $1 \%$ significance level.

Table 8. Estimates of GJR GARCH $(1,1)$ with BSE 100

\begin{tabular}{llll}
\hline $\begin{array}{l}\text { Mean Equation } \\
\text { Parameters }\end{array}$ & Coefficients & Z-statistic & p-value \\
\hline$\beta_{0}$ & 0.6301 & $1.7801^{*}$ & 0.0021 \\
$\beta_{I}$ & 3.6780 & $2.5670^{*}$ & 0.0001 \\
$\gamma_{1}$ & -0.34590 & 4.6780 & 0.0025 \\
Variance Equation & & & 0.0000 \\
$\boldsymbol{\alpha}_{\boldsymbol{0}}$ & 0.06701 & $3.4860^{*}$ & 0.0000 \\
$\alpha_{1}$ & 0.4180 & $7.7890^{*}$ & 0.0000 \\
$\beta_{1}$ & 0.5023 & $3.562^{*}$ & 0.0000 \\
$\lambda_{1}$ & 0.0239 & $3.753^{*}$ & 0.0000 \\
$\delta_{2}($ Dummy) & 0.6590 & $2.856^{*}$ & \\
Residual diagnostics Test statistic P. value & & \\
LB-Q(16) & 8.190 & 0.5230 & 0.5452 \\
LB ${ }^{2}$ Q(16) & 5.8521 & 0.2231 & \\
LM-(10) & 5.670 & 0.7801 & \\
F-Test & 0.579 & & \\
\hline
\end{tabular}

Note: * Indicates $1 \%$ significance level.

The coefficient of the dummy variable for most of indices in the variance equation was positive and significant this implies that the spot market volatility in India had increased during recent financial crisis. The results also showed that asymmetric effect was present in the volatility of the stock returns.

Thus the volatility of the most of stock returns had increased during the post crisis period as compared to the pre-crisis period. This was due to the continuous withdrawal foreign institutional investors from Indian stock market. Therefore, foreign and domestic investors had lost confidence in the stock market.

\section{Concluding Remarks}

The global financial crisis originated in the United States, spread all over the world, and had a drastic impact on the stock markets in the developed and the emerging economies. The aim of this paper is to analyze the effect of the global financial crisis on the volatility in Indian stock market. Daily closing price of indices in the NSE and the BSE from March $1^{\text {st }}, 2005$ to December $30^{\text {th }} 2012$ were considered for the analysis. The study employed GJR GRACH model to capture asymmetric volatility of NSE and BSE. Our results demonstrate that negative news causes greater volatility impact than positive news. Our results finally lead us to conclude that the global financial crisis negatively impacted the mean returns and increased the volatility in the Indian stock markets. 


\section{References}

Adamu, A. (2010). “Global Financial Crisis and Nigerian Stock Market Volatility” conference on 'Managing the Challenges of Global Financial Crisis in Developing Economies' (pp. 1-27). Nasarawa State University, Keffi, Nigeria.

Anaraki, N. K. (2011). The European stock market impulse to the US financial crisis. Journal of International Business and Cultural Studies, 1-12.

Angabini, A., \& Wasiuzzaman, S. (2010). Impact Of The Global Financial Crisis On The Volatility Of The Malaysian Stock Market. International Conference on E-business, Management and Economics, 2010(1-26).

Arouri, M. E. H. (2010). Global financial crisis, liquidity pressure in stock markets and efficiency of central bank $\begin{array}{llll}\text { interventions. } & \text { Applied } & \text { Financial }\end{array}$ http://dx.doi.org/10.1080/09603100903493195

Chong, C. Y. (2011, March). Effect of Sub-prime Crisis on U.S. Stock Market Return and Volatility. Global Economy and Finance Journal, 4(1), 102-111.

Glosten, L., Jagannathan, R., \& Runkle, D. (1993). On the relation between expected value and the volatility of the nominal excess return on stocks. Journal of Finance, 48, 1779-1801. http://dx.doi.org/10.1111/j.1540-6261.1993.tb05128.x

Karunanayake, Indika, Valadkhani, Abbas, \& O’Brien, M. (2010). An Empirical Analysis of International Stock Market Volatility Transmission. University of Wollongong, Working Paper, (9-10), 1-22.

Manda, K. (2010). Stock Market Volatility during the 2008 Financial Crisis working paper series 1 (pp. 1-32). The Leonard N. Stern School of Business, Glucksman Institute for Research in Securities Markets.

Olowe, R. A. (2009). Stock Return, Volatility And The Global Financial Crisis in an Emerging Market: The Nigerian Case. International Review of Business Research Papers, 5(4), 426-447.

Saha, S., \& Chakrabarti, G. (2011). Financial Crisis and Financial Market Volatility Spill-Over. The International Journal of Applied Economics and Finance, 5, 185-199. http://dx.doi.org/10.3923/ijaef.2011.185.199

Sed'a, P. (2012). Impact of the global financial crisis on stock market volatility: Evidence from Central European stock market. Proceedings of 30 ${ }^{\text {th }}$ International Conference Mathematical Methods in Economics, 787-792.

\section{Appendix A}

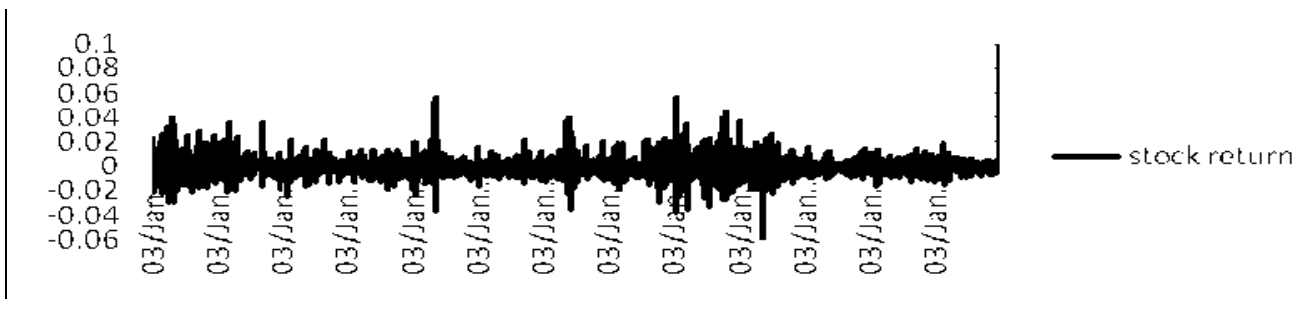

Figure A1. BSE-30 sensex returns

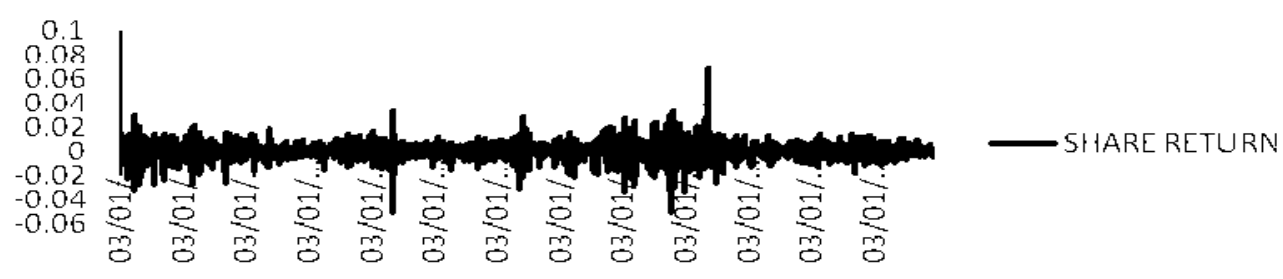

Figure A2. BSE-100 stock returns 


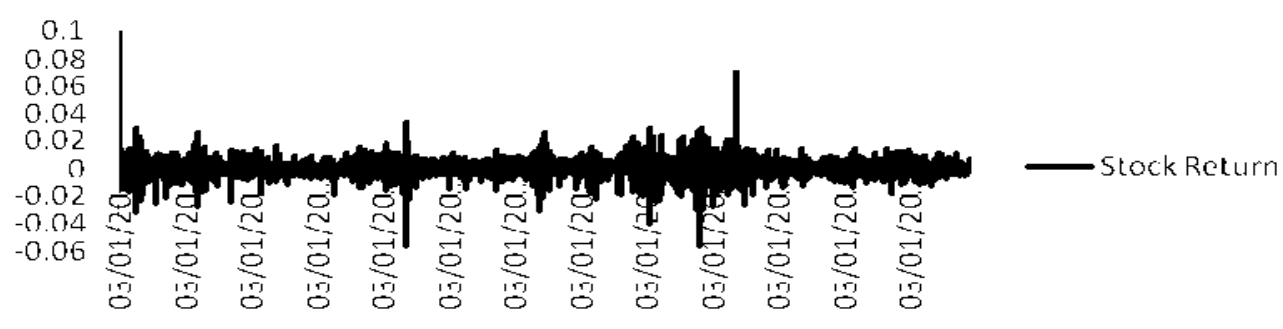

Figure A3. NIFTY 50 returns

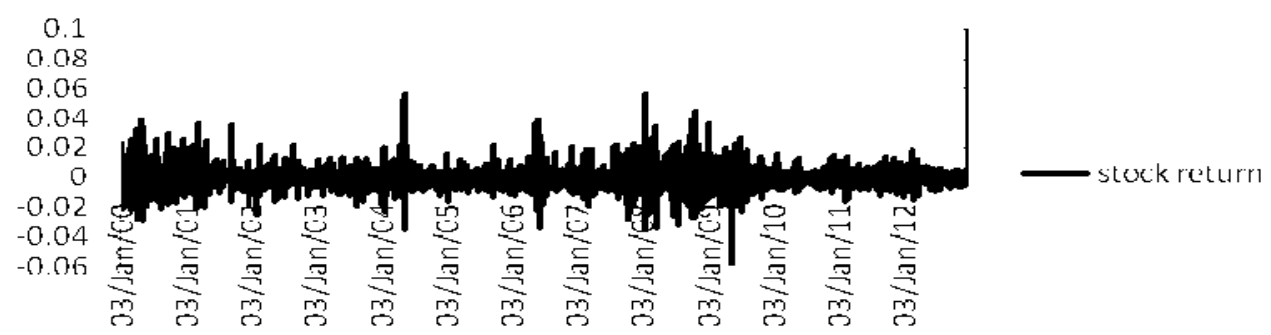

Figure A4. Nifty junior returns

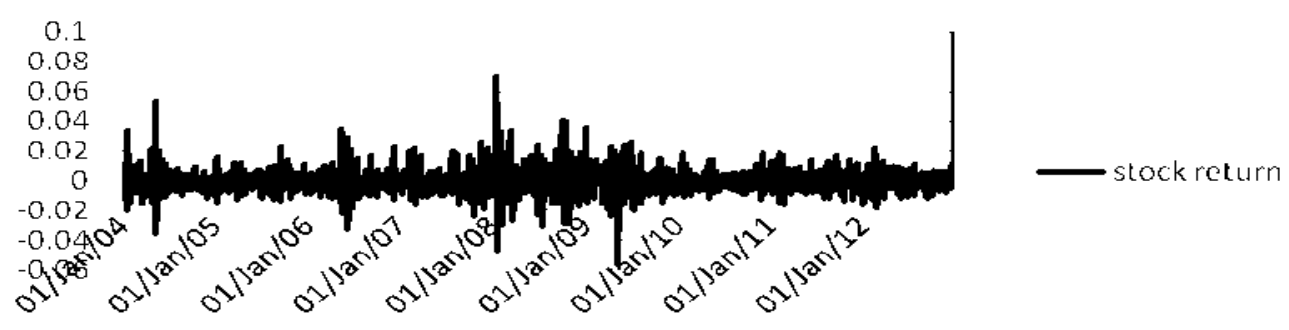

Figure A5. Nifty mid-cap

\section{Copyrights}

Copyright for this article is retained by the author(s), with first publication rights granted to the journal.

This is an open-access article distributed under the terms and conditions of the Creative Commons Attribution license (http://creativecommons.org/licenses/by/3.0/). 